\title{
ZINC AND CADMIUM ACCUMULATION IN MAIZE (ZEA MAYS L.) AND THE CONCENTRATION OF MOBILE FORMS OF THESE METALS IN SOIL AFTER APPLICATION OF FARMYARD MANURE AND SEWAGE SLUDGE
}

\author{
Krzysztof Gondek \\ Chair of Agricultural and Environmental Chemistry \\ University of Agriculture in Krakow
}

\begin{abstract}
The total content of heavy metals in soil does not indicate bioavailability of these elements after introduction of sewage sludge to soil. Determination of the rate of heavy metal mobilization from sewage sludge after its application to soil is very important for agricultural practice since it allows us to asses the rate at which these elements pass into the soil solution, which conditions their uptake by plants. This research has been conducted to assess the effect of farmyard manure and sewage sludge fertilization on the amounts of zinc and cadmium absorbed by maize and the content of their mobile forms in soil. The research consisted of a three-year pot experiment. Farmyard manure and sewage sludge fertilization resulted in larger total yields of maize biomass (for the 3-year period of the investigations) than harvested from the treatments where only mineral compounds were used as fertilizers. Irrespectively of the fertilizer dose, the total (for 3 years) amounts of zinc and cadmium absorbed by maize were the highest in the treatments where only mineral salts were added and $\mathrm{Zn}$ and $\mathrm{Cd}$ quantities taken up by maize in the first year of the experiment contributed to this result. Fertilization with farmyard manure and sewage sludge did not cause any significant mobilization of mobile zinc and cadmium forms in soil after the first year of the research. As a result of organic matter mineralization and progressing soil acidification, in the second and third year of the research, the content of mobile forms of the elements in soil increased, although to a lesser degree than under the influence of exclusively mineral treatment.
\end{abstract}

Key words: zinc, cadmium, maize, soil, sewage sludge, farmyard manure.

dr hab. inż. Krzysztof Gondek, Chair of Agricultural and Environmental Chemistry, University of Agriculture in Krakow, e-mail: rrgondek@cyf-kr.edu.pl 


\title{
AKUMULACJA CYNKU I KADMU W KUKURYDZY (ZEA MAYS L.) ORAZ ZAWARTOŚĆ MOBILNYCH FORM TYCH PIERWIASTKÓW W GLEBIE PO ZASTOSOWANIU OBORNIKA I OSADÓW ŚCIEKOWYCH
}

\begin{abstract}
Abstrakt
Kryterium ogólnej zawartości metali ciężkich nie ujmuje ich biologicznej przyswajalności po wprowadzeniu osadu ściekowego do gleby. Określenie tempa uruchamiania metali ciężkich z osadów ściekowych po ich wprowadzeniu do gleby jest bardzo ważne dla praktyki rolniczej, pozawala bowiem ocenić szybkość przechodzenia tych pierwiastków do roztworu glebowego, co warunkuje ich pobranie przez rośliny. Celem badań była ocena wpływu nawożenia obornikiem i osadami ściekowymi na pobranie cynku i kadmu przez kukurydzę oraz zawartość mobilnych form tych pierwiastków w glebie. Badania prowadzono w 3-letnim okresie w warunkach doświadczenia wazonowego. W wyniku nawożenia obornikiem i osadami ściekowymi osiągnięto większe sumaryczne plony biomasy kukurydzy (w 3-letnim okresie badań) w porównaniu z zebranymi w obiektach, w których zastosowano wyłącznie nawożenie mineralne. Sumaryczne (z 3 lat) pobranie cynku i kadmu przez kukurydzę, niezależnie od dawki nawożenia, było największe w obiektach, w których zastosowano wyłącznie sole mineralne, do czego przyczyniły się ilości Zn i Cd pobrane przez kukurydzę w pierwszym roku badań. Nawożenie obornikiem i osadami ściekowymi nie spowodowało istotnego uruchomienia mobilnych form cynku i kadmu w glebie po pierwszym roku badań. W wyniku mineralizacji materiałów organicznych oraz postępującego zakwaszenia gleb w drugim i trzecim roku badań, zawartość mobilnych form badanych pierwiastków w glebie się zwiększyła, chociaż w mniejszym stopniu niż pod wpływem wyłącznego nawożenia mineralnego.
\end{abstract}

Słowa kluczowe: cynk, kadm, kukurydza, gleba, osad ściekowy, obornik.

\section{INTRODUCTION}

A considerable content of fertilizer components and organic substance in sewage sludge justifies their environmental use. The fertilizer value of sewage sludge goes beyond supplying nutrients to plants which ensure their proper growth and development. It also advantageously affects physical, chemical and biological properties of soil (KLASA et al. 2007, GŁAB, GONDEK 2008).

In Poland, the use of municipal sewage sludge in agriculture, beside microbiological concerns, raises questions about heavy metal content. The content of these elements in sewage sludge depends on the sorption capacity of solid particles in sewage from which heavy metals are trasnferred to sludge (Rosik-Dulewska et al. 2007). The total content of heavy metals in sewage sludge is a primary albeit insufficient criterion in assessment of the usability of sewage sludge in the environment, including agriculture. The total content of heavy metals does not diminish their bioavailability after introducing sewage sludge to soil. Determination of the rate of mobilization of heavy metal from sewage sludge after its application to soil is very important for agricultural practice since is allows us to assess the rate at which they pass into the soil solution, which conditions their uptake by plants (Fuentes et al. 2006, RENOUx et al. 2007). 
The aim of this research has been to assess the effect of fertilization with farmyard manure and sewage sludge on amounts of zinc and cadmium absorbed by maize and the abundance of their mobile forms in soil.

\section{MATERIAL AND METHODS}

The effect of fertilization with farmyard manure and sewage sludge on zinc and cadmium amounts absorbed by maize and the content of their mobile forms in soil has been investigated in a three-year pot experiment. The experimental design comprised the following treatments (each in four replications): 0 - without fertilization; NPK-I - mineral treatment; NPK-II mineral treatment; FYM-I - farmyard manure, FYM-II - farmyard manure; SSA-I - sewage sludge A, SSA-II - sewage sludge; SSB-I - sewage sludge B and SSB-II - sewage sludge B. The treatment symbols marked with I or II indicate the fertilization levels. The research was conducted on soil of the granulometric composition corresponding to sandy silt loam (determined using Casagrande's method modified by Prószyński) collected from the arable layer $(0-20 \mathrm{~cm})$ of an arable field in southern Poland $(10 \mathrm{~km}$ west of Krakow). Before the experiment started, basic physical and chemical properties of the soil material were determined using methods described by OsTROWsKA et al. (1991). The results are presented in Table 1. The experiment was conducted in PVC pots with $5.0 \mathrm{~kg}$ of air-dried soil.

Table 1

Some properties of soil before the establishment of the experiment

\begin{tabular}{|l|c|c|}
\hline \multicolumn{2}{|c|}{ Determination } & Value \\
\hline $\mathrm{pH} \mathrm{KCl}$ & & 5.69 \\
\hline Hydrolitic acidity & $\left(\mathrm{mmol}(+) \mathrm{kg}^{-1}\right.$ d.m. $)$ & 23.4 \\
\hline Total N & \multirow{2}{*}{$\left(\mathrm{g} \mathrm{kg}^{-1}\right.$ d.m. $)$} & 1.25 \\
\cline { 1 - 1 } Organic $\mathrm{C}$ & & 13.36 \\
\hline \multirow{2}{*}{ Total $\mathrm{Zn}$} & \multirow{2}{*}{$\left(\mathrm{mg} \mathrm{kg}^{-1}\right.$ d.m. $)$} & 78.3 \\
\cline { 1 - 1 } Total $\mathrm{Cd}$ & & 0.65 \\
\hline
\end{tabular}

Sewage sludge originated from two municipal treatment plants (a mechanical and biological system) from Krzeszowice (SSA) and Niepołomice (SSB) situated in the Province of Malopolska. Before collecting samples, sewage sludge was subjected to aerobic stabilization in isolated open tanks, where aeration process went on constantly at ambient temperature. The aeration process lasted for 5 days for sludge from Krzeszowice (SSA) and 8 
days for sludge from Niepołomice (SSB). Afterwards, sewage sludge was dewatered on filtration beds. The process lasted for 2 months for SSA sludge and 3 months for SSB sludge. The final stage of the stabilization of sludge from Krzeszowice was hygenization using hydrated calcium. After dewatering, sewage sludge from Niepołomice was removed to a windrow and left.

Farmyard manure used for the experiment originated from pigs fed with commercial concentrates. The experiment made use of farmyard manure after 6-month storage on a manure plate.

In fresh samples of farmyard manure and sludge, $\mathrm{pH}$ was measured with a potentiometer. Dry mass content (at $105^{\circ} \mathrm{C}$ for $12 \mathrm{~h}$ ) and total nitrogen content after mineralization of samples in concentrated sulphuric acid were determined using Kjeldahl's method. In dried and ground material, organic matter concentration was assessed after calcination of samples in a muffle furnace (at $550^{\circ} \mathrm{C}$ for 8 hours). The concentrations of phosphorus, potassium, zinc and cadmium were assessed after mineralization of samples in a muffle furnace (at $450^{\circ} \mathrm{C}$ for $5 \mathrm{~h}$ ) and the content of ash was measured by dissolving in diluted (1:2) nitric acid (V). The concentration of phosphorus was determined using the vanadium-molybdenum method in a Backman DU 640 spectrophotometer. Potassium was assessed by flame photometry (FES). Zinc and cadmium were assessed using the ICP-AES method in a JY 238 Ultrace apparatus. The determinations were performed using the methods described by BARAN and TURSKI (1996). Chemical characteristics of farmyard manure and sewage sludge can be found in Table 2.

Table 2

\begin{tabular}{|c|c|c|c|c|}
\hline \multicolumn{2}{|c|}{ Determination } & \multirow{2}{*}{$\begin{array}{r}\text { FYM } \\
189\end{array}$} & \multirow{2}{*}{$\begin{array}{c}\text { Sewage sludge A } \\
\text { (SSA) }\end{array}$} & \multirow{2}{*}{$\begin{array}{c}\text { Sewage sludge B } \\
\text { (SSB) }\end{array}$} \\
\hline Dry matter & $\left(\mathrm{g} \mathrm{kg}^{-1}\right)$ & & & \\
\hline $\mathrm{pH} \mathrm{H} \mathrm{H}_{2} \mathrm{O}$ & & 6.22 & 6.12 & 5.73 \\
\hline Total N & \multirow{3}{*}{ (g kg-1 d.m.) } & 25.1 & 17.2 & 42.4 \\
\hline Total P & & 22.6 & 5.48 & 19.3 \\
\hline Total K & & 26.7 & 2.71 & 2.81 \\
\hline Organic matter & (g kg-1 d.m.) & 679 & 353 & 553 \\
\hline Total Zn & \multirow{2}{*}{ (mg kg-1 d.m.) } & 531 & 899 & 1683 \\
\hline Total Cd & & 1.28 & 2.71 & 2.25 \\
\hline
\end{tabular}

In order to meet the restrictions regulating application of sewage sludge to soil as described in the Regulation of the Minister for the Natural Environment (Regulation... 2002), prior to the experiment, soil material was limed with chemically pure $\mathrm{CaO}$. The dose was determined on the basis 
of the soil's total hydrolytic acidity. After four weeks, farmyard manure, sewage sludge and mineral salts (NPK) were supplied to soil. Doses of farmyard manure and sewage sludge were calculated on the basis of their nitrogen concentrations. Two levels of nitrogen fertilization were applied. A single dose of nitrogen supplied with fertilizers was $0.109 \mathrm{~g} \mathrm{~N} \mathrm{~kg}^{-1}$ soil d.m. and a double dose was $0.218 \mathrm{~g} \mathrm{~N} \mathrm{~kg}^{-1}$ soil d.m. Phosphorus and potassium were supplemented at an equal level to the amounts introduced with fertilizers in soil of all the treatments (except the control): $0.114 \mathrm{~g}$ and $0.228 \mathrm{~g} \mathrm{P} \mathrm{kg}^{-1}$ soil d.m. as aqueous solution of $\mathrm{Ca}\left(\mathrm{H}_{2} \mathrm{PO}_{4}\right)_{2} \cdot \mathrm{H}_{2} \mathrm{O}$ and $0.134 \mathrm{~g}$ and $0.269 \mathrm{~g}$ $\mathrm{K} \mathrm{kg}^{-1}$ soil d.m. in the form of aqueous solution of $\mathrm{KCl}$. In the second and third year of the experiment, supplementary fertilization with chemically pure salt solutions was applied: nitrogen as $\mathrm{NH}_{4} \mathrm{NO}_{3}$, phosphorus as $\mathrm{Ca}\left(\mathrm{H}_{2} \mathrm{PO}_{4}\right)_{2} \cdot \mathrm{H}_{2} \mathrm{O}$ and potassium as $\mathrm{KCl}$. The quantities of the elements supplied in the second and third year of the experiment were identical: $0.40 \mathrm{~g}$ and $0.80 \mathrm{~g} \mathrm{~N} ; 0.10 \mathrm{~g}$ and $0.20 \mathrm{~g} \mathrm{P}$ and 0.70 and $1.40 \mathrm{~g} \mathrm{~K} \mathrm{pot}^{-1}$, respectively for the single (I) and double (II) dose.

Maize, c.v. San (FAO 240), was grown as 5 plants per pot. Maize (for green fodder) was harvested at the stage of 7-9 leaves. The period of plant vegetation was 47 days in the first, 66 days in the second and 54 days in the third year. During the experiment, the plants were watered with distilled water to $50 \%$ of soil maximum water capacity.

After the harvest, the plants were dried (at $70^{\circ} \mathrm{C}$ ) to constant weight and dry mass yield of aerial parts and roots was determined. After drying, the biomass was crushed in a laboratory mill and subjected to chemical analysis.

In order to determine the concentrations of zinc and cadmium content, crushed plant material, aerial parts and roots separately, was mineralized in a muffle furnace (at $450^{\circ} \mathrm{C}$ for $5 \mathrm{~h}$ ) and the remains were dissolved in diluted (1:2) nitric acid. The concentrations of $\mathrm{Zn}$ and $\mathrm{Cd}$ were determined using the ICP-AES method in a JY 238 Ultrace apparatus.

The soil material collected after the growing season from each pot was brought to air-dried state, thoroughly mixed and sifted through a sieve with $1 \mathrm{~mm}$ mesh. The soil's $\mathrm{pH}$ was measured with a potentiometer in $1 \mathrm{~mol}$ $\mathrm{dm}^{-3} \mathrm{KCl}$ suspension (OstrowsKa et al. 1991) and the total and mobile forms of zinc and cadmium were determined. Concentrations of total forms of these elements were assessed after mineralization of samples in a muffle furnace (at $550^{\circ} \mathrm{C}, 8 \mathrm{~h}$ ) and dilution of the remains in a mixture of concentrated nitric and chlorous acids (2:1) (Ostrowska et al. 1991). Mobile $\mathrm{Zn}$ and Cd forms were extracted from the soil by means of $1 \mathrm{~mol} \mathrm{dm}^{-3} \mathrm{NH}_{4} \mathrm{NO}_{3}$ solution (Del Castilho, RIx 1992). In the solutions and filtrates thus obtained, the concentrations of the analysed elements were assessed using the ICPAES method in a JY 238 Ultrace apparatus.

The analyses of plant and soil material were conducted in four replications, but organic material and initial soil samples were tested in two repli- 
cations and a plant reference sample NCS DC73348 (China National Analysis Center for Iron \& Steel) or soil reference AG-2 (AgroMAT) were added to each series of the analysed material. A result was regarded reliable if the relative standard deviation (RSD) error did not exceed 5\%.

The results were verified statistically according to the constant model where the investigated factor was fertilization. One-way ANOVA was conducted and the significance of differences was estimated using Fisher's LSD test at the significance level $p<0.01$ (STANISZ 1998).

\section{RESULTS AND DISCUSSION}

Total maize yields (aerial parts and roots) for the three years from the fertilized treatments were significantly larger (by between 45 and 92\%) than the amount of biomass harvested from the non-fertilized treatment (Table 3). Farmyard manure and sewage sludge fertilization resulted in larger yields of maize biomass (during the three year period) than mineral fertilizers. Biomass yields, higher than gathered on the treatments where farmyard manure and municipal sewage sludge were used, were produced on the treatment receiving mineral fertilizers only in the first year of the experiment (Table 3). In the subsequent years, maize yielded better in the treatments where farmyard manure or sewage sludge were used, particularly in bigger doses. Such an effect did not occur when plants were fertilized with mineral salts.

In the treatment receiving mineral fertilisers, the highest share of maize biomass in the total yield for three years (50\%) was noted in the first year

Table 3

Yields biomass of maize in each year of the experiment (g d.m. pot $^{-1} \pm$ standard error; $n=4$ )

\begin{tabular}{|c|c|c|c|c|}
\hline Treatment & 1st year & 2nd year & 3rd year & Total yield \\
\hline 0 & $55.2^{d e f} \pm 1.7$ & $27.1^{a} \pm 0.3$ & $27.4^{a} \pm 1.2$ & $109.7^{a} \pm 2.5$ \\
\hline NPK-I & $85.0^{j} \pm 2.9$ & $40.6^{b c} \pm 1.6$ & $49.6^{c d} \pm 0.8$ & $175.2^{c} \pm 3.5$ \\
\hline NPK-II & $76.0^{h i j} \pm 5.4$ & $31.2^{a b} \pm 0.6$ & $52.7^{c d e} \pm 1.1$ & $159.9^{b} \pm 5.6$ \\
\hline FYM-I & $61.8^{\text {defg }} \pm 1.8$ & $56.5^{d e f} \pm 1.5$ & $60.8^{\text {defg }} \pm 1.7$ & $179.1^{c} \pm 3.2$ \\
\hline FYM-II & $57.5^{\text {defg }} \pm 2.1$ & $74.8^{h i j} \pm 3.1$ & $64.3^{e f g h} \pm 3.0$ & $196.6^{d} \pm 2.8$ \\
\hline SSA-I & $57.0^{\text {defg }} \pm 2.0$ & $55.3^{d e f} \pm 0.5$ & $69.4^{g h i} \pm 2.3$ & $181.7^{c} \pm 2.9$ \\
\hline SSA-II & $59.0^{\text {defg }} \pm 1.1$ & $75.7^{h i j} \pm 1.4$ & $64.1^{e f g h} \pm 1.2$ & $198.8 \mathrm{~d}^{e} \pm 1.9$ \\
\hline SSB-I & $58.9^{\text {defg }} \pm 2.9$ & $63.4^{\text {efgh }} \pm 1.4$ & $52.5^{c d e} \pm 1.0$ & $174.8^{c} \pm 3.9$ \\
\hline SSB-II & $64.6^{\text {efgh }} \pm 2.2$ & $78.8^{i j} \pm 2.4$ & $67.4^{f g h i} \pm 1.9$ & $210.8^{e} \pm 2.8$ \\
\hline
\end{tabular}

Means followed by the same letters in a column did not differ significantly at $p<0.01$ according to Fisher's LSD test. 
of the investigations, irrespective of the fertilizer dose (Table 4). A reverse tendency was observed for the treatments where farmyard manure and sewage sludge were applied, since a higher proportion of maize biomass in the total (for three years) yield was recorded in the second or third year of the experiment.

Table 4

Contribution (\%) of biomass yield of maize in each year of the experiment

\begin{tabular}{|l|c|c|c|}
\hline \multicolumn{1}{|c|}{ Treatment } & $1^{\text {st }}$ year & $2^{\text {nd }}$ year & $3^{\text {rd }}$ year \\
\hline 0 & 50.3 & 24.8 & 24.9 \\
\hline NPK-I & 48.5 & 23.2 & 28.3 \\
\hline NPK-II & 47.4 & 19.6 & 33.1 \\
\hline FYM-I & 34.5 & 31.5 & 34.0 \\
\hline FYM-II & 29.2 & 38.0 & 32.7 \\
\hline SSA-I & 31.3 & 30.5 & 38.2 \\
\hline SSA-II & 29.7 & 38.1 & 32.2 \\
\hline SSB-I & 33.7 & 36.3 & 30.0 \\
\hline SSB-II & 30.6 & 37.4 & 32.0 \\
\hline
\end{tabular}

The effect of mineral fertilization on shaping the amount of crop yields is more thoroughly documented than the effect of natural or organic fertilizer application, particularly organic waste materials (RAUN, JOHNSON 1999, Blecharczyk, Mąecka 2005, IdZiak 2005, StęPIEŃ et al. 2005). The present experiment demonstrated an advantageous effect of farmyard manure and sewage sludge fertilization on the amount of maize biomass yields at the optimal water access. The investigations conducted by SiEnKIEwICZ (2003) showed that maize produces higher yield $\mathrm{w}$ receiving farmyard manure fertilization than exclusively mineral fertilization. The result of FYM, according to the author, intensifies itself in the subsequent crop rotations. Positive effect of farmyard manure on crop yields after a prolonged period of its application was observed in other experiments (BlecharczyK, MAŁECKa 2005, SchmidT et al. 2000). In their research comparing the fertilizer effect of farmyard manure and sewage sludge, KALEMBASA and KuzIEMSKA $(1991,1992)$ observed that in the first year of sewage sludge application its fertilizer value expressed by maize crop yield was lower than the farmyard manure value; it was approximately identical in the second and third year and only in the fourth year it was better than that of farmyard manure. In the present investigations, the yield forming effects of farmyard manure and sewage sludge were comparable and the differences between the biomass amounts from individual treatments were not significant. A beneficial effect of sewage sludge fertilization on biomass yield was also reported by KRZYWY and WoŁOsZYK (1997) and SKownońska et al. $(1999,2001)$ observed a decrease in maize biomass 
after farmyard manure and sewage sludge application in relation to mineral fertilization. The author obtained the lowest maize yield after the application of farmyard manure and sewage sludge in the first year of the experiment, which coincides with the results presented in this work. Most probably, maize response in PAtoRczyK-PytLIK's study, expressed as a decline in biomass yield, was caused by a considerable heavy metal burden in the sewage sludge.

Zinc plays an important role in plants, mainly by activating many enzymes. It should also be emphasized that when municipal sewage sludge is used for fertilization, $\mathrm{Zn}$ is supplied to soil in relatively larger amounts than other trace elements. Total amounts of zinc taken up by maize aerial parts and roots were the highest in the first year of the experiment in the treatments where mineral fertilizers were used (Table 5). In the second and third year maize absorbed more zinc in the treatments where farmyard manure

Table 5

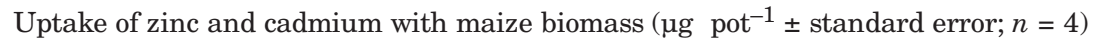

\begin{tabular}{|c|c|c|c|c|}
\hline \multirow{2}{*}{ Treatment } & $1^{\text {st }}$ year & $2^{\text {nd }}$ year & $3^{\text {rd }}$ year & Total uptake \\
\hline & \multicolumn{4}{|c|}{$\mathrm{Zn}$} \\
\hline 0 & $825^{a} \pm 123$ & $353^{a} \pm 8$ & $426^{a} \pm 18$ & $1604^{a} \pm 120$ \\
\hline NPK-I & $1745^{b} \pm 84$ & $516^{a b} \pm 15$ & $999^{b} \pm 26$ & $3260^{c} \pm 90$ \\
\hline NPK-II & $1902^{b} \pm 140$ & $914^{c d} \pm 50$ & $1861^{d} \pm 67$ & $4677^{e} \pm 150$ \\
\hline FYM-I & $618^{a} \pm 47$ & $551^{a b} \pm 18$ & $1001^{b} \pm 29$ & $2170^{b} \pm 66$ \\
\hline FYM-II & $657^{a} \pm 19$ & $1122^{d} \pm 97$ & $1450^{c} \pm 68$ & $3229^{c} \pm 105$ \\
\hline SSA-I & $697^{a} \pm 41$ & $647^{b c} \pm 13$ & $1121^{b} \pm 27$ & $2465^{b} \pm 69$ \\
\hline SSA-II & $792^{a} \pm 64$ & $1533^{e} \pm 106$ & $1813^{d} \pm 28$ & $4138^{d} \pm 115$ \\
\hline SSB-I & $668^{a} \pm 22$ & $772 b^{c} \pm 38$ & $1066^{b} \pm 43$ & $2506^{b} \pm 42$ \\
\hline SSB-II & $879^{a} \pm 60$ & $1548^{e} \pm 135$ & $1717^{d} \pm 56$ & $4144^{d} \pm 190$ \\
\hline Treatment & \multicolumn{4}{|c|}{$\mathrm{Cd}$} \\
\hline 0 & $6.37^{a} \pm 1.14$ & $3.28^{a} \pm 0.61$ & $1.73^{a} \pm 0.37$ & $11.38^{a} \pm 1.62$ \\
\hline NPK-I & $15.24^{b} \pm 1.28$ & $3.71^{a} \pm 0.29$ & $10.32^{b} \pm 0.86$ & $29.27^{b c} \pm 0.75$ \\
\hline NPK-II & $24.23^{c} \pm 3.51$ & $13.78^{c d} \pm 0.37$ & $33.66^{d} \pm 2.07$ & $71.67^{e} \pm 3.82$ \\
\hline FYM-I & $4.62^{a} \pm 0.29$ & $3.17^{a} \pm 0.32$ & $7.44^{a b} \pm 0.56$ & $15.23^{a} \pm 0.69$ \\
\hline FYM-II & $4.30^{a} \pm 0.60$ & $11.60^{b c} \pm 1.56$ & $17.44^{c} \pm 2.36$ & $33.34^{c d} \pm 1.71$ \\
\hline SSA-I & $5.13^{a} \pm 0.35$ & $4.23^{a} \pm 0.47$ & $6.61^{a b} \pm 0.96$ & $15.97^{a} \pm 0.75$ \\
\hline SSA-II & $6.32^{a} \pm 0.66$ & $14.47^{c d} \pm 2.20$ & $20.68^{c} \pm 2.54$ & $41.47^{d} \pm 4.93$ \\
\hline SSB-I & $5.33^{a} \pm 0.67$ & $6.48^{a b} \pm 0.56$ & $7.92^{a b} \pm 0.84$ & $19.73^{a b} \pm 1.31$ \\
\hline SSB-II & $7.34^{a} \pm 1.59$ & $18.46^{d} \pm 2.92$ & $18.96^{c} \pm 2.77$ & $44.76^{d} \pm 6.19$ \\
\hline
\end{tabular}

Means followed by the same letters in a column did not differ significantly at $p<0.01$ according to Fisher's LSD test. 
or municipal sewage sludge were applied, particularly in larger doses. Also WoŁoszYK et al. (2009) point to higher quantities of zinc taken up by plants fertilized with bigger doses of sewage sludge. On the other hand, Bowszys et al. (2009) indicated the form of the applied sewage sludge (dried or granulated sludge) as another factor, apart form a sludge dose, which may condition the content and amounts of the element absorbed by plants.

Cadmium is a crucial element for plant development. Because of its considerable mobility in soil, it is relatively easily absorbed by plants. Maize absorbed the highest quantities of cadmium in the first year in the treatment with a double dose of mineral salts (Table 5). In the second and third year of the experiment, generally greater uptakes of cadmium were found in the treatment where maize was fertilized with double doses of farmyard manure or sewage sludge. Total (for three years) amounts of cadmium taken up by maize, irrespective of the fertilizer dose, were the highest in treatments where exclusively mineral fertilizers were used (Table 5). The results diagree with the research conducted by PAтоRCZYK-PутLIK (2001), who revealed higher total amounts of cadmium absorbed by maize in treatments where processed sewage sludge was applied. However, it should be emphasized that the organic materials used by the author had considerably bigger cadmium concentrations. The research conducted by PiotrowsKA and GAŁCZYŃSKA (1990) indicated that excessive accumulation of cadmium in plants resulted from application of high doses of sewage sludge which were considerably loaded with this element.

Soil $\mathrm{pH}$ is one of the most important indicators of soil fertility, most rapidly changing under the influence of fertilization. After three years, a negative effect of particularly bigger dose of mineral fertilizers (Table 6)

Table 6

Soil reaction ( $\mathrm{pH} \mathrm{KCl} \pm$ standard error; $n=4)$ after harvest of plants

\begin{tabular}{|l|c|c|c|}
\hline \multicolumn{1}{|c|}{ Treatment } & $1^{\text {st }}$ year & $2^{\text {nd }}$ year & $3^{\text {rd }}$ year \\
\hline 0 & $5.90^{\text {defgh }} \pm 0.01$ & $5.94^{\text {ffgh }} \pm 0.02$ & $5.81^{c d e} \pm 0.01$ \\
\hline NPK-I & $5.78^{c d} \pm 0.01$ & $5.69^{b c} \pm 0.09$ & $5.59^{b} \pm 0.01$ \\
\hline NPK-II & $5.77^{c d} \pm 0.01$ & $5.70^{b c} \pm 0.03$ & $5.42^{a} \pm 0.01$ \\
\hline FYM-I & $5.98^{g h} \pm<0.01$ & $5.90^{\text {defgh }} \pm 0.03$ & $5.71^{b c} \pm 0.01$ \\
\hline FYM-II & $6.02^{h} \pm 0.01$ & $5.84^{\text {def }} \pm 0.01$ & $5.63^{b} \pm 0.02$ \\
\hline SSA-I & $5.99^{h} \pm<0.01$ & $5.92^{\text {efgh }} \pm<0.01$ & $5.69^{b c} \pm 0.01$ \\
\hline SSA-II & $6.00^{h} \pm 0.01$ & $5.96^{f g h} \pm 0.01$ & $5.69^{b c} \pm 0.01$ \\
\hline SSB-I & $5.93^{\text {efgh }} \pm 0.02$ & $5.92^{\text {efgh }} \pm 0.01$ & $5.69^{b c} \pm<0.01$ \\
\hline SSB-II & $5.96^{f g h} \pm 0.01$ & $5.86^{\text {defgh }} \pm 0.02$ & $5.61^{b} \pm 0.01$ \\
\hline
\end{tabular}

Means followed by the same letters in a column did not differ significantly at $p<0.01$ according to Fisher's LSD test. 
on soil pH was most pronounced. The acidifying effect of mineral fertilizers has been confirmed in papers by STRACZYŃsKa (1998) and Kopeć (2000). Fertilization with farmyard manure and sewage sludge decreased the soil acidification rate, mainly owing to introducing a considerable amount of alkalizing elements and organic matter. According to JARECKI (1991), treatment with natural or organic fertilizers stabilizes soil reaction. BARAN et al. (1996) also noticed a beneficial effect of fertilization, particularly with bigger doses of sewage sludge, on soil $\mathrm{pH}$.

Application of waste materials as fertilizers rises some doubts, especially due to a threat of natural environment pollution with heavy metals (MosQUERA-LosAdA et al. 2010). Beside the total heavy metal content in waste materials, also the rate of release of their mobile forms to the soil solution

Table 7

Content of mobile forms of zinc and cadmium in soil $\left(\mathrm{mg} \mathrm{kg}^{-1} \pm\right.$ standard error; $n=4$ ) after harvest of plants

\begin{tabular}{|c|c|c|c|}
\hline \multirow{2}{*}{ Treatment } & $1^{\text {st }}$ year & $2^{\text {nd }}$ year & $3^{\text {rd }}$ year \\
\hline & \multicolumn{3}{|c|}{$\mathrm{Zn}$} \\
\hline 0 & $0.403^{a b c} \pm 0.01$ & $0.610^{a b} \pm 0.08$ & $0.593^{a} \pm 0.02$ \\
\hline NPK-I & $0.514^{e} \pm 0.01$ & $0.757^{c d} \pm 0.02$ & $0.976^{d} \pm 0.02$ \\
\hline NPK-II & $0.507^{d e} \pm 0.02$ & $0.824^{d} \pm 0.03$ & $1.288^{e} \pm 0.02$ \\
\hline FYM-I & $0.356^{a b} \pm 0.01$ & $0.547^{a} \pm 0.02$ & $0.708^{b} \pm 0.02$ \\
\hline FYM-II & $0.349^{a} \pm 0.02$ & $0.664^{a b c} \pm 0.01$ & $0.867^{c} \pm 0.02$ \\
\hline SSA-I & $0.433^{b c d} \pm 0.02$ & $0.671^{a b c} \pm 0.01$ & $0.856^{c} \pm 0.04$ \\
\hline SSA-II & $0.448^{c d e} \pm 0.01$ & $0.703^{b c d} \pm 0.01$ & $0.996^{d} \pm 0.02$ \\
\hline SSB-I & $0.458^{c d e} \pm 0.03$ & $0.600^{a b} \pm 0.02$ & $0.845^{c} \pm 0.02$ \\
\hline SSB-II & $0.481^{c d e} \pm 0.02$ & $0.849^{e} \pm 0.03$ & $1.267^{e} \pm 0.02$ \\
\hline Treatment & \multicolumn{3}{|c|}{$\mathrm{Cd}$} \\
\hline 0 & $0.014^{c} \pm<0.001$ & $0.014^{a} \pm<0.001$ & $0.014^{a} \pm<0.001$ \\
\hline NPK-I & $0.018^{d} \pm<0.001$ & $0.019^{b c} \pm<0.001$ & $0.023_{f} \pm<0.001$ \\
\hline NPK-II & $0.017^{d} \pm<0.001$ & $0.023^{c} \pm<0.001$ & $0.034^{g} \pm<0.001$ \\
\hline FYM-I & $0.011^{a b} \pm<0.001$ & $0.013^{a} \pm<0.001$ & $0.015^{a b} \pm<0.001$ \\
\hline FYM-II & $0.010^{a} \pm<0.001$ & $0.013^{a} \pm<0.001$ & $0.019^{c d e} \pm<0.001$ \\
\hline SSA-I & $0.013^{b c} \pm<0.001$ & $0.014^{a} \pm<0.001$ & $0.017^{b c} \pm<0.001$ \\
\hline SSA-II & $0.013^{b c} \pm<0.001$ & $0.013^{a} \pm<0.001$ & $0.021^{\text {def }} \pm<0.001$ \\
\hline SSB-I & $0.014^{c} \pm<0.001$ & $0.014^{a} \pm<0.001$ & $0.019^{b c d} \pm<0.001$ \\
\hline SSB-II & $0.014^{c} \pm<0.001$ & $0.015^{a b} \pm<0.001$ & $0.022^{e f} \pm<0.001$ \\
\hline
\end{tabular}

Means followed by the same letters in a column did not differ significantly at $p<0.01$ according to Fisher's LSD test. 
and their arresting in soil are vary important. The concentrations of zinc mobile forms in soil were diverse, not only between the applied fertilization treatments but it also between the years of the experiment (Table 7). The lowest zinc concentrations extracted with $\mathrm{NH}_{4} \mathrm{NO}_{3}$, irrespective of the applied fertilization, were assessed in the soil after the first year of the investigations. After three years, the content of mobile forms of zinc generally increased in soil of all treatments, and the share of mobile zinc forms in the total content also grew, especially after the application of a double dose of the fertilizer (Figure 1). Also BARAN et al. (2001) associated an increase in zinc soil concentrations, including soluble zinc compounds, with doses of sewage sludge, but at the same time pointed to a dependence between the rate of mobilization of this element into the soil solution and the date of sewage sludge application. PATORCZYK-PYTLIK, SPIAK (1996) observed considerable changes in the content of zinc extracted with $1 \mathrm{~mol} \mathrm{dm}^{-3} \mathrm{HCl}$ solution from soil fertilized with sewage sludge, which they interpreted as conditioned by a considerable amount of this element supplied with sewage sludge. In the author's own investigations, progressing soil acidification has a significant influence on increasing mobile zinc forms.

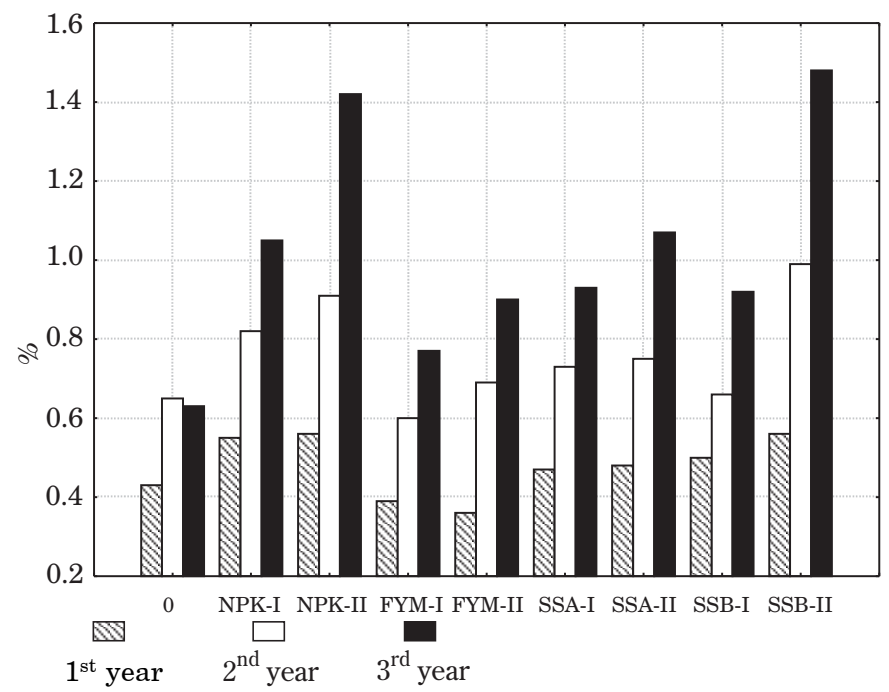

Fig. 1. Contribution (\%) of mobile forms in the total content of zinc in soil

Irrespective of the applied fertilization, the greatest quantities of cadmium extracted using $\mathrm{NH}_{4} \mathrm{NO}_{3}$ were found in the soil from the treatment where a double dose of mineral salts was applied (Table 7). Farmyard manure or sewage sludge supplied to soil, irrespective of their dose, did not lead to any marked diversification of the contents of mobile cadmium forms in soil, no matter which dose of the fertilizers was applied. Observations of 
the dynamics of concentrations of cadmium mobile forms in soil reveal both greater diversification and higher content of this $\mathrm{Cd}$ form after the third year of the experiment. Also the share of mobile cadmium forms in its total content raised visibly (Figure 2 ).

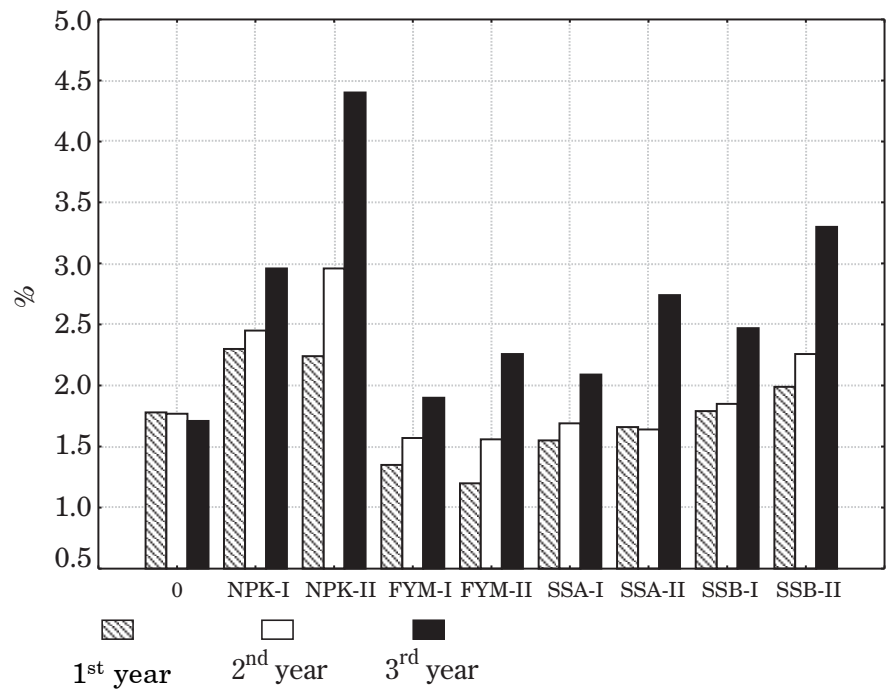

Fig. 2. Contribution (\%) of mobile forms in the total content of cadmium in soil

In soil, cadmium belongs to highly mobile elements. Its mobility is conditioned by several factors, including soil pH (BASTA et al. 2005). This research revealed gradual acidification of soil, irrespective of the applied treatment, which favoured increase in mobile forms of this element. Also IżewsKA et al. (2006) demonstrated considerably higher concentrations of soluble cadmium forms in soil fertilized with sewage sludge.

\section{CONCLUSIONS}

1. Fertilization with farmyard manure and sewage sludge allowed us to obtain larger yields of maize biomass (for the 3-year period of investigations) than in the treatments where exclusively fertilization with mineral compounds was used.

2. Total (for 3 years) amounts of zinc and cadmium absorbed by maize, irrespectively of a fertilization dose, were the highest in the treatments where only mineral salt fertilization was applied, an effect to which quantities of $\mathrm{Zn}$ and $\mathrm{Cd}$ absorbed by maize in the first year of the experiment greatly contributed. 
3. Fertilization with farmyard manure and sewage sludge did not cause any significant mobilization of mobile zinc and cadmium forms in soil after the first year of the experiment. As a result of mineralization of organic materials and progressing soil acidification in the second and third year of the investigations, the content of the mobile forms of the examined elements in soil raised, although to a lesser degree than under the influence of exclusively mineral fertilization.

\section{REFERENCES}

Baran S., Bielińska E. J., Wiśniewski J., WóJcikowska-Kapusta A. 2001. The effect of purple willow cultivation on $\mathrm{Zn}$ and $\mathrm{Cu}$ contents and activity of dehydrogenases and phosphatases in light soil fertilized with sewage sludge. Zesz. Nauk. AR w Szczecinie, 223, ser. Rolnictwo, 89: 7-14. (in Polish)

Baran S., Flis-Bujak M., Turski R., Żukowska G. 1996. Changes of physico-chemical properties of light soil fertilized with sewage sludge. Roczn. Glebozn., 47 (3/4): 123-130. (in Polish)

Baran S., Turski R. 1996. Handbook of waste and sewage sludge disposal. Wyd. AR w Lublinie, ss. 136. (in Polish)

Basta N. T., Ryan J. A., Chaney R. L. 2005. Trace element chemistry in residual-treated soil: Key concepts and metal bioavailability. J. Environ. Qual., 34: 49-63.

Blecharczyk A., MaŁecka I. 2005. Effect of fertilization and cropping systems on spring barley yield stability in a long-term experiment since 1957. Fragm. Agronom., XII, 1(85): 11-20. (in Polish)

Bowszys T., Wierzbowska J., Bowszys J. 2009. Content and removal of $\mathrm{Cu}$ and $\mathrm{Zn}$ with harvested crops grown on soil fertilized with composted municipal sewage sludge. J. Elementol., 14(1): 23-32.

Del Castilho P., Rix J. 1992. Ammonium acetate extraction for soil heavy metal speciation; model aided soil test interpretation. Intern. J. Environ. Anal. Chem., 51: 59-64.

Fuentes A., Llorens M., Saez J., Agullor M.S., Perez-Morin A.B. Ortuno J.F., Meseguer V.F. 2006. Ecotoxicity, phytotoxicity and extractability of heavy metals from different stabilized sewage sludges. Environ. Pollut., 143: 355-360.

GŁĄB T., GondeK K. 2008. Effect of organic amendments on morphometric properties of macropores in stagnic gleysol soil. Pol. J. Environ. Stud., 17(2): 209-214.

IDZIAK R. 2005. Reaction of spring barley, oat and their mixtures to nitrogen fertilization. Fragm. Agronom., XXII, 1(85): 397-405. (in Polish)

Iżewska A., Krzywy E., WoŁoszyk Cz., BAlcer K. 2006. Heavy metal concentrations in light soil in the third year following the application of sewage sludge and composts produced of sewage sludge. Zesz. Probl. Post. Nauk Rol., 512: 173-181. (in Polish)

JARECKI M. 1991. Cooperation of organic and mineral fertilizers in shaping the quantity and quality of yield and chemical properties of light soil. Zesz. Nauk. AR w Szczecinie, ser. Rozpr. 132, p. 70. (in Polish)

Kalembasa S., Kuziemska B. 1991. The effect of sludge on the yield of selected crops and their heavy metal concentrations. Rocz. Glebozn., 42: 230-235. (in Polish)

Kalembasa S., Kuziemska B. 1992. The evaluation of fertilizing of activated waste sludges. Part I. The influence of the kind and time of application of activated waste sludges on the yield of some plants. Pol. J. Soil Sci., 25(1): 47-52.

Klasa A., GotKiewicz W., Czapla J. 2007. Modifications of physico-chemical soil properties following application of sewage sludge as soil amendment. J. Elementol., 12(4): 278-302. 
Kopeć M. 2000. Dynamics of yielding and quality changes of mountain meadow sward over 30 years of fertiliser experiment. Zesz. Nauk. AR w Krakowie, ser. Rozpr. 267, ss. 84. (in Polish)

KrzYwy E., Woєoszyк C. 1997. Effect of raw and composted sludges from urban sewage treatment plants on yielding and cadmium and nickel contents in rye-grass. Zesz. Probl. Post. Nauk Rol., 448, 149-155. (in Polish)

Mosquera-Losada M.R., Munoz-Frreiro N., Rigueiro-Rodriguez A. 2010. Agronomic chracterisation of different types of sewage sludge: Policy implications. Waste Manag., 30(3): 492-503.

Ostrowska A., Gawliński A., SzczubiaŁKa Z. 1991. Methods of analysis and assessment of soils and plants. Wyd. IOŚ, Warszawa, ss. 324. (in Polish)

Ратовсzук-Рутцiк B. 2001. Agrochemical evaluation of different techniques of preparing compost from sewage sludge. Zesz. Nauk. AR we Wrocławiu, ser. Rozpr., 401, ss. 104. (in Polish)

PatPrczyк-Pyтlik B., Spiak Z. 1996. Dynamics of content of zinc in soil and plants in result of use of FYM and of sewage sludge. Zesz. Nauk. AR w Szczecinie, 172, ser. Rolnictwo, 62: 451-460. (in Polish)

Piotrowska M., GazczyńskA B. 1990. The effect of sewage sludge application to soil on yielding and chemical composition of perennial ryegrass. Part 2. Trace element concentrations. Pam. Puł., 96: 111-120. (in Polish)

Raun W., Johnson G. 1999. Improving nitrogen use efficiency for cereal production. J. Agronom., 91: 357-363.

Renoux A.Y., Rochelean S., Sarrazin M., Sunahara G.I. Blais J.F. 2007. Assessment of a sewage sludge treatment on cadmium, copper and zinc bioavailability in barley, ryegrass and earthworms. Environ. Pollut., 145(1): 41-50.

Rosik-Dulewska Cz., Karwaczyńska U., G€owala K. 2007. Environmental use of municipal sewage sludge and composts produced of municipal waste - fertilizer value vs. environmental hazards. Zesz. Nauk. Wydz. Bud. i Inż. Środ., Uniw. Opolski, 23: 137-153. (in Polish)

Resolution of the Minister of the Natural Environment of 1 August, 2002 on municipal sewage sludge. Journal of Laws, No. 134, item 1140. (in Polish)

Schmidt L., Warnstorff K., Derfel H., Leinweber P., Lange H., Merbach W. 2000. The influence of fertilization and rotation on soil organic matter and plant yields in the long-term Eternal Rye trial in Halle (Saale), Germany. J. Plant Nutr. Soil Sci., 163(6): 639-648.

Sienkiewicz S. 2003. Studies on the effect of farmyard manure and mineral fertilizers on fertility productivity of soil. Wyd. UWM, ser. Rozpr. i Monogr., 74, ss. 121. (in Polish)

Skowrońska M., Wiater J., DęвICki R. 1999. Yielding, content and balance of nitrogen, phosphorus and potassium depending on the way of sewage sludge application. Folia Univ. Agric. Stein., 200, Agric., 77: 337-342. (in Polish)

Stanisz A. 1998. Comprehensible course of statistics based on Statistica PL with examples from medicine. Wyd. Statsoft Polska, ss. 362. (in Polish)

Stępień W., Mercik S., Szara E. 2005. The effect of long-term potassic and phosphoric fertilising and liming on yields and composition of plants. Fragm. Agronom., XXII, 1(85): 283-289. (in Polish)

StRĄCZÝ́sKa S. 1998. Changes of $p H$ and sorption capacities of sandy soils under the influence of many-year mineral, organic and organic-mineral fertilization. Zesz. Probl. Post. Nauk Rol., 456: 165-168. (in Polish)

WoŁoszyk Cz., Iżewska A., Krzywy-Gawrońska E. 2009. Content, uptake and utilization by plant sof copper, manganese and zinc from municipal sewage sludge and wheat straw. J. Elementol., 14(3): 593-604. 